\title{
Delivering community benefits acts as insurance for the survival of small protected areas such as the Abe Bailey Nature Reserve, South Africa
}

\author{
Authors: \\ Susan J. Taylor ${ }^{1}$ \\ Doreen Atkinson ${ }^{1}$ \\ Affiliations: \\ ${ }^{1}$ Centre for Development \\ Support, University of the \\ Free State, South Africa \\ Correspondence to: \\ Susan Taylor \\ Email: \\ rhtaylor@icon.co.za \\ Postal address: \\ PO Box 339, Internal 100, \\ Bloemfontein 9300, \\ South Africa \\ Dates: \\ Received: 15 Feb. 2011 \\ Accepted: 02 Dec. 2011 \\ Published: 21 May 2012 \\ How to cite this article: \\ Taylor, S.J. \& Atkinson, D., \\ 2012, 'Delivering community \\ benefits acts as insurance \\ for the survival of small \\ protected areas such as the \\ Abe Bailey Nature Reserve, \\ South Africa', Koedoe 54(1), \\ Art. \#1043, 9 pages. http:// \\ dx.doi.org/10.4102/koedoe. \\ v54i1.1043
}

(C) 2012. The Authors.

Licensee: AOSIS

OpenJournals. This work

is licensed under the

Creative Commons

Attribution License.
The Abe Bailey Nature Reserve (ABNR) in the Gauteng Province of South Africa is largely unknown and offers little to attract visitors. The biological integrity of the ABNR is challenged by the urban poverty in Khutsong, the reserve's immediate neighbour. Relations between Khutsong and the nature reserve had been hostile for decades as a result of the 'fortress' style of conservation protection used for the ABNR. However, this situation provided the Gauteng Directorate of Nature Conservation with an opportunity to experiment with identifying and transferring benefits to the community, as well as establishing an effective buffer zone between the nature reserve and the informal settlements of Khutsong. Following an initial rapid rural appraisal and ongoing liaison through specifically appointed project managers, an outreach programme containing two natural resource-based projects was developed. As a result, better relations were established between the ABNR and its neighbouring community for the first time since the nature reserve was established in 1977. This acted as 'insurance' during violent public protests and vandalism in the Khutsong border demarcation dispute (2005-2007), but may not be enough to secure the nature reserve into the future.

Conservation implications: Small protected areas may not be effective in ensuring their biological integrity in the long term, but working cooperatively with existing and future neighbours is an essential strategy to optimise conservation activities in small reserves such as the ABNR.

\section{Introduction}

\section{Protected areas and sharing benefits}

While the primary role of protected areas is the conservation of species diversity, biodiversity conservation, along with sustainable resource management, can and must result in material benefits to neighbouring communities. The United Nations Convention on Biological Diversity (Secretariat of the Convention on Biological Diversity 2008) states that protected areas are important tools for the conservation of biological and often supply important ecosystem goods and services and must form the cornerstone of sustainable development strategies; yet, they are often under-resourced to play these roles. Additionally, individual protected areas are becoming increasingly isolated and ever more in contact with growing human populations, who, at the same time, are struggling to find land and resources on which to survive, specifically in developing countries (Straede \& Treue 2006).

Conservation and poverty reduction need to be tackled together for best results and, as such, achieving local cooperation and support without jeopardising conservation goals has become a top priority for most parks around the world (Adams et al. 2004; Wittmayer \& Büscher 2010). This predicts an ongoing battle between the need to keep protected areas intact and the needs and impact of the people outside these areas. To ensure that protected areas achieve local cooperation and survive into the future, a deep understanding of the socio-economic dynamics that determine the current and future use of land resources in and around the protected area is essential (DeFries et al. 2007). Community-based conservation and development has become the prevailing paradigm of conservation organisations and development donors over the last 20 years (Browder 2002; Gjertsen 2005). However, there is considerable complexity in ensuring that this happens in practice.

Considerable management, social, financial and ecological skills, as well as the latest conceptual thinking by park management, needs to be brought to bear on attaining community support. More often than not, successfully managing large parks through trying to reconcile the aspirations of the local people has been difficult to achieve (Mbile et al. 2006) and the many failures since the 1980s have resulted in a proliferation of consultative processes to engage with communities living outside or within protected areas. 
The large, donor-funded community-based integrated conservation and development projects, which have formed a well-known approach to dealing with both conservation and poverty through the attempt to reconcile park management with local needs and aspirations, have drawn criticism from conservation biologists for failing to ensure adequate protection of biodiversity (Browder 2002). Also, other approaches, such incentive-based programmes, which aim to foster local stewardship by delivering benefits tied directly to local biodiversity conservation by local people, have been tried with mixed results (Spiteri \& Nepal 2008). These have resulted in recent experimental approaches that try to incorporate elements of adaptive management and institutional development, as well as form new partnership models with stakeholders and create the vertical integration of site-level work with policy initiatives (Wells \& McShane 2004).

Baker, Milner-Gulland and Leader-Williams (2011) point out that conflicts between protected-area managers and local people are common, but the drivers of such conflicts are rarely analysed. The lack of case studies and data limit opportunities to identify strategies that reduce conflict and the magnitude of resulting threats to conservation; this lack of evidence and analysis may set up some community programmes for failure. Reid et al. (2004) point out a growing trend towards protectionism, possibly because of the many failures and ongoing challenges in making the relationship between people and biodiversity conservation work. As an alternative to both community biodiversity partnership models and protectionism, Sodhi et al. (2010) warn that 'local people must be provided with alternative sustenance opportunities and basic education in addition to environmental outreach to reduce their reliance on protected forests and to enhance conservation support'.

In South African, nature conservation has moved away from a strictly protectionist approach to the recognition that biodiversity must benefit local people (Botha, Witkowski \& Cock 2006; Mulder, Caro \& Msago 2007; Wittmayer \& Büscher 2010; Wynberg 2002). The principle that biodiversity and protected areas must benefit people is contained in a 'White paper on the conservation and sustainable use of South Africa's biological diversity' (Department of Environmental Affairs and Tourism 1997) and in the National Environmental Management: Protected Areas Act 2003 (Act No. 57 of 2003) (Republic of South Africa 2003), which states that protected areas must be able to deliver some needed benefit to neighbours and that mechanisms to ensure this must be outlined in that protected area's management plan.

In South Africa, larger conservation projects, such as the Maloti-Drakensberg Transfrontier Conservation and Development Project, are established with the aim of playing a large role in local development (Wittmayer \& Büscher 2010). Also, South African National Parks (SANParks) plays a large developmental role in the areas surrounding the national parks, through, for example, contractual parks (Reid et al. 2004). The challenge is for the smaller protected areas in South Africa (i.e. municipal and provincial reserves), which have fewer financial and skills resources, to engage with this complexity.

\section{Buffer zones and land use changes outside protected areas}

In general, natural ecosystems are under enormous pressure from the growing demands of human development (Guo, Zhang \& Li 2010; Iwamura et al. 2010). Although protected areas now cover over $12 \%$ of the terrestrial surface of the earth, many fail to protect species and ecological processes as originally envisioned. Results of recent studies suggest that a critical reason for this failure is an everincreasing contrast between the protected area and the surrounding matrix of often highly altered land outside the protected area (Seiferling et al. 2011).

To mitigate against the impact of human development, international best practice for protected areas includes creating 'buffer zones' where the interface between park and people is managed. These can include areas designated for conservation, community forestry, limited resource extraction or agriculture (Bajimaya 2006; Lynagh \& Urich 2002; SANParks n.d.). Buffer zones are intended as areas where communities can engage with natural resource use and generate revenue from biodiversity rather than having access to the protected area itself (Bajimaya 2006). Whilst the intention of buffer areas is to resolve parkpeople conflicts over resource use, Straede and Treue (2006) show that, in Nepal, there is a growing gap between local people's need for natural resources and their rights to satisfy them on a legal basis in the buffer areas, meaning that the situation is unsustainable in the longer term, and this is the situation for many protected areas. Other studies show that, inevitably, the buffer zone degrades from overuse and the local communities begin to make forays into the protected area itself to satisfy their needs (Lynagh \& Urich 2002). Constant monitoring and adaptive management is needed to ensure a 'win-win' situation between protected area and neighbours and that buffer strategies may have to change over the years to ensure sustainability (Lynagh \& Urich 2002). Ma et al. (2009) show that even in a biosphere situation meant to accommodate human activity, the declared buffer zone becomes over-utilised with serious consequences for the biodiversity within the 'core' region of the biosphere reserve. Integrating biodiversity conservation and the development of local communities is therefore a major challenge (Ma et al. 2009).

\section{Protected areas and human development}

In some rural areas, there are new concerns that the protected areas themselves may cause the human population density to increase artificially on the outside of parks because of the opportunities and benefits protected areas offer in a world of decreasing resource availability (Wittemyer 
et al. 2008). Countering this finding, Joppa, Loarie and Pimm (2009) showed that when population growth does occur near protected areas, it results from a general expansion from nearby population centres. Working with the Kafue National Park in Zambia, Joppa et al. (2009) found that, over time, distant rural population centres grew outwards in all directions, threatening Kafue National Park. The national park was 'simply in the way' of human population expansion. Inspection of many other parks shows this to be a common trend (Joppa et al. 2009). This is the situation in Gauteng, where urban development is beginning to engulf small protected areas such as the Abe Bailey Nature Reserve (ABNR). In other developed countries, Gimmi et al. (2011) also found that human density tended to increase outside protected areas through urban development and increased residential market values of land near 'nature'.

The availability of land to declare an appropriate buffer zone for a protected area is a critical constraint because of the frequent lack of available land surrounding the protected area. In the urban or peri-urban environment, buffer zones are especially difficult to create because land use is usually already designated, or land is highly priced.

\section{The vulnerability of small protected areas}

The impact of human development on the outside of large reserves is mitigated to some extent by the size of the reserve, but for small reserves, the impact can mean that, over time, the biodiversity within the reserve begins to deteriorate, following the dominant land-use change pattern into which they are located (Maiorano, Falcucci \& Boitani 2008). As such, Maiorano et al. (2008) suggest that small parks will not be viable in the long term, especially if they are allowed to become 'islands' in a human-dominated landscape. Identification of appropriate and effective management opportunities for a small nature reserve depends on defining the biodiversity attributes of concern; identifying landscape connections to delineate strong ecological interactions between the protected area and its surrounding landscape and identifying socioeconomic dynamics that determine current and future use of land resources in and around the protected area. The challenge is to identify management opportunities that result in the maintenance of ecological function in the wider landscape without imposing undue restrictions on human land use (DeFries et al. 2007).

The ABNR is a small (4197 ha) nature reserve located within a human-dominated landscape (urban development, agriculture and mining activities) and this paper reviews some of its struggles to remain as a functioning entity on the edge of urban development, conserve biodiversity and deliver benefits to the neighbouring community. Its biodiversity attributes include a sample of Carletonville dolomite grassland (listed as vulnerable), a genetically pure herd of black wildebeest, Connochaetes gnou (DNA tested), a population of the White-tailed Rat, Mystromys albicaudatus, a wetland, an extensive cave system which is part of the dolomitic geology of the area, as well as 262 bird species.
No planning work has been undertaken to understand how this nature reserve contributes to ecosystem or species conservation in the wider landscape.

Outside the reserve, at the ABNR-Khutsong interface, the land use has already been designated as urban, with bigger agricultural and agri-business expansion also planned for the area. The Merofong City integrated development plan (IDP) (Merofong Municipality 2011) makes scant mention of the nature reserve, merely citing that it is an 'impediment to the northwards expansion of urban Khutsong and Wielverdiend'. The notion of a protected area playing a role in determining surrounding land use, as urged by DeFries et al. (2007), would be very difficult to achieve at the ABNR without considerably more resources.

\section{Methods}

\section{Procedure}

A qualitative approach was used to analyse, post hoc, the history and outcomes of community outreach programme initiated in 2000. This paper is compiled from the personal experiences and notes of the primary author, who was one of the project initiators involved at a strategic level at the Gauteng Department of Agriculture Conservation and Environment (GDACE) from 1999 to 2006, as well as from two formal interviews held with the officer-in-charge at the ABNR in 2010 and 2011, and from interviews with two of the former project managers of this project, the late Madire Malepe (pers. comm., 21 July 2008) and Dr Thato Shale (pers. comm., 30 October 2010).

Departmental records of the rapid rural appraisal (RRA) held between residents from Khutsong and the GDACE in 2000 were used to review the findings of this initial community consultation. The RRA sessions probed general social and economic needs of the community, as well as how the community related to the ABNR, and sought to identify any ecological, spiritual or other needs that the nature reserve could provide, which would improve the working relationship between the community and the reserve. In preparation, the governmental group from the GDACE was given a one-day training session on how to conduct an RRA (most of the departmental participants in the project were nature conservation officials with no formal training in social science methods), held by the late James Mascarenhas, an expert in participatory research practice (Mascarenhas 1991). Although notes were taken at the time, no detailed data were recorded at the RRA sessions. The RRA techniques used with the Khutsong groups included mapping, matrix ranking, seasonality diagrams, Venn diagrams and timelines (J. Mascarenhas, pers. comm., 24 October 2000).

An initial liaison with Merofong municipal councillors in 2000 guided the selection of community groups for the RRA. The five groups interviewed were a home-based care group called 'Millennium Women', a home-based care group called 'Home for the Aged', a youth group, the Bambanani 
Group of traditional healers, and a group of residents of the New Mandela Village informal settlement adjacent to the nature reserve.

\section{Study area}

\section{Abe Bailey Nature Reserve}

The ABNR falls within the Merafong City Municipality and is a provincial nature reserve in Gauteng Province, located $7 \mathrm{~km}$ north-west of Carltonville, between $26^{\circ} 16^{\prime} \mathrm{S}$ and $26^{\circ} 20^{\prime} \mathrm{S}$ and $27^{\circ} 17^{\prime} \mathrm{E}$ and $27^{\circ} 22^{\prime} \mathrm{E}$ (Eber 1998). Sir Abe Bailey, a wealthy 'randlord' from Johannesburg's early years, originally owned the land and used it as a hunting preserve around the turn of the 20th century (Eber 1998). In 1977, the Far West Rand Dolomitic Association (FWRDA), who still own much of the land in the Far West Rand, made two farms available to the Transvaal Branch of the Wildlife Society of Southern Africa for the creation of a nature reserve, and a five-year lease was signed (Eber 1998).

In 1980, the FWRDA offered further land adjoining the reserve to the Wildlife Society. The Wildlife Society was unable to afford such a venture and so offered the reserve to the then Transvaal Provincial Administration. Transvaal Nature Conservation assumed control of the reserve on the 01 April 1982. On 11 May 1988, a 50-year lease was signed between the Transvaal Provincial Administration and FWRDA for the ABNR. This lease was transferred subsequently to the Gauteng Provincial Government on 10 May 1994 (Eber 1998).

Whilst the ABNR was proclaimed in 1977 and was intended to be a multi-racial recreational facility, this never came to fruition and the reserve was severely underutilised by all race groups during the apartheid years (Eber 1998). There were many management factors which alienated the residents of Khutsong from the nature reserve over the years. Primarily, the reserve had a history of 'brutal enforcement of its policy of fences, arrests and fines' (Eber 1998). Prior to the democratic elections in 1994, the rangers reportedly patrolled the perimeter with semi-automatic firearms. In 1992, 251 dogs were shot on the reserve, escalating conflict with the community. Other ongoing community-related problems on the reserve included arson, poaching of wildlife, removal of fences and the use of the nature reserve as a short cut to a main road leading into Carletonville (Eber 1998).

By the late 1990s, the ABNR was in a dilapidated condition, had never reached its potential as a recreational resource for Black people in the area and was facing closure (Eber 1998). The boundary fence between New Mandela Village and the ABNR had been erected and removed many times and, by 1999, shacks, rubbish dumps, soccer fields and stands of maize could be found within the nature reserve, adding to the picture of dereliction. Thus, in 1997, nature conservation officials formally petitioned the GDACE Head of Department for permission to set up a task team to investigate options for the ABNR to try and resolve the ongoing conflict with Khutsong (Eber 1998). Officials explained the need to investigate the potential of the reserve as an asset to the people of Khutsong. Finally, in 2000, this request was taken up with an RRA as the first formal post-1994 engagement between the GDACE and the Khutsong residents.

The nature reserve presently covers an area of \pm 9780 ha, after the addition of land donated by the FWRDA and the local mining houses (Merafong Municipality 2011).

\section{Profile of Khutsong township}

Khutsong is a crowded urban settlement that borders on the ABNR. Khutsong was established in 1958 as an apartheid township to relocate people living in slums that had developed on White-owned farms, as well as to provide housing for mine labour (Botha 2003). The township is composed of many formal and informal sections. One of the poorest of these is the New Mandela Village, an informal settlement located on unsafe land (i.e. land with a prevalence of developing sinkholes) without basic services, and which is the immediate neighbour of the ABNR. The western border of the nature reserve is also the Gauteng-North West provincial border and the border of Merofong Municipality with North West Province. The presence of unstable dolomite geology limits development in the area.

After the first national democratic elections in 1994, Khutsong was designated as part of the Merofong Municipality in Gauteng. Service delivery was reported to be notably poor, experiencing little or no change since Khutsong was neglected under apartheid (Botha 2003). There was mounting public frustration and violence within Khutsong in the post1994 period in relation to service delivery (Botes et al. 2007). In 2003, a social scan undertaken by Botha (2003) estimated that unemployment in Merofong Municipality ranged from $25 \%$ to close to $60 \%$ in different parts of Khutsong. Poverty was very prevalent and numerous households were heavily dependent on child and/or disability grants and/ or pensions. Young men lacked jobs and future prospects, even though many had completed formal schooling (Botha 2003). Nevertheless, Khutsong was a diverse and active place and Botha (2003) identified dozens of community groups in Khutsong, including women's groups, HIV and/or AIDS home-based care groups, faith groups, youth groups, trade unions, men's stokvel [savings] groups, food garden groups, sports and soccer clubs, arts and culture groups, health groups and business groups.

From 2005 to 2007, local Merofong Municipality residents, particularly those living in Khutsong, engaged in a dispute with the national government over their unwillingness to be incorporated into North West Province. Residents feared the new demarcation would make them worse off in terms of service delivery. The impact of this unrest was manifested through the destruction of public and private property in Khutsong, costing an estimated R70 million in damage by April 2006 (Botes et al. 2007; Mavungu 2011). The violence ended in 2009 when a government decision was gazetted that Khutsong would be returned to Gauteng Province. 


\section{Results}

\section{Community needs relating to the Abe Bailey Nature Reserve}

The RRA held in 2000 with the selected community groups at Khutsong revealed a plethora of needs, concerns and opportunities for action, even though many of these could not be taken further by GDACE's Nature Conservation or Agricultural Directorates as they fell outside the departmental mandate. In some cases, the issues were referred to relevant government departments. The RRA also noted specifically how the community related to the ABNR. Key RRA findings from each of the five groups relating to the ABNR are summarised in the subsections below.

\section{The 'Care for the Aged' home-based care group}

The older persons looked after by the Care for the Aged group had little knowledge of the ABNR and its biodiversity objectives, even though they had lived in the area for decades. What was important for this group was land for gardening and a 'working centre' where vegetable gardening could be undertaken in a safe environment. There was also the suggestion that able-bodied elderly people could be employed by the reserve, rather than only young people being selected for work such as burning fire breaks.

\section{'Millennium Women', a women's group involved in home-based care}

The members of this group were involved in caring for HIV and/or AIDS patients and the aged, but stated that little support comes from government and that, generally, the health services in the areas are poor. There were many orphans in the area who had suffered the death of parents caused by HIV-related and/or AIDS-related diseases. The group also assists the elderly to claim their social security grants. The women's group had a very good understanding of the ABNR and had several suggestions on how it could become relevant to the Khutsong people. They did not express any direct 'needs' for themselves. The women stated that the ABNR should be utilised for the following:

- agriculture (food security projects and community cattle grazing)

- environmental education

- medicinal plants propagation (in a nursery on the reserve).

The Millennium Women's group also requested access to the nature reserve to collect 'greens' (morogo), which refers to a group of at least three different dark-green leafy vegetables found throughout southern Africa, harvested for human consumption and which represent a seasonal-free food source.

\section{Khutsong youth group}

This was a group of young people who met regularly at the one of the small clinics in the informal settlement. The youth group included 16 young men aged between the ages of 16 and 30 years. The youth group was aware of the ABNR and that it promoted nature conservation. Its members were also aware that the reserve sometimes offered temporary work opportunities and that this was a benefit. They also acknowledged that the nature reserve provided 'free medicinal plants'. Negative issues from the youth included the statement that the rangers 'beat us up instead of taking us to the police station if we are caught on the nature reserve and they think we are stealing animals' (Khutsong youth group member, 25 years).

The youth did not suggest any 'needs' for themselves, but suggested that there is a need to renovate the education centre at the ABNR and run an awareness programme about nature conservation. The youth group mentioned that the reserve is not accessible to local people because they do not know anything about it and suggested information about the nature reserve should be presented in local schools.

\section{Bambanani Group of traditional healers of Khutsong}

The government consultation only reached one traditional healer group who called themselves the Bambanani Group, although continued liaison with Khutsong residents revealed that there were at least six traditional healing organisations in Khutsong (Botha 2003). It was known by the GDACE officials that the Bambanani Group acted as gatekeepers and inhibited other traditional healers or healer groups from participating in activities organised by the nature reserve. This was difficult to overcome with limited resources and, as such, the Department resigned itself to dealing with the Bambanani Group. However, the dealings with this group have proved to be productive over the years and it has been recognised that the aim of the project was not to address all concerns and help all groupings within Khutsong.

Fourteen traditional healers (twelve women of various ages and two men of retirement age) from the Bambanani Group attended the initial RRA workshop in 2000. The traditional healers in this group were all very poor and stated that their patients were even poorer and very often could not pay for treatment.

Most of the plants that they used in their practices and which they considered important medicinally do not come from the ABNR, but are bought from suppliers from Kwazulu-Natal. The plants the traditional healers harvested in the reserve, or from the surrounding farm lands, are relatively insignificant to them, so access for the sustainable harvesting of these plants in the ABNR was not a big need for the healers. What was important for the Bambanani Group was access to land to grow the specific plants they needed. The traditional healer group requested that provincial government allow them to plant orchards of medicinal tree species and wetlands plants for their use within the boundaries of the ABNR. They gave the GDACE a confidential list of their required species.

\section{New Mandela Village informal settlement residents}

This group (about 40 men and women) informed the GDACE officials that the municipality did not provide them with basic municipal services and that they lived in a situation 
of dire need. The lack of jobs was a serious problem. Of the 46 households represented at the RRA session, only seven people had formal incomes. Informal sources of income for New Mandela Village residents include selling paraffin and vegetables, cooking and selling fresh maize cobs, fixing radios, sewing, informal maize farming, working in Carletonville as gardeners and domestic workers, and wood carving for the tourist trade. People in the area also did not have access to land for household cultivation purposes and, as a result, food security was a key issue.

It was enlightening to understand how New Mandela Village residents perceived the 'good things' about the ABNR. They stated that they received free meat, free firewood, free morogo, free living space (land on which to locate their shacks) and free fencing and poles from the nature reserve. In terms of the nature reserve management and its requirement to protect government assets such as game animals and infrastructure, these 'benefits' would all be illegally acquired and essentially constituted theft and poaching.

The negative statements about the ABNR included: not enough jobs on offer, that they were chased away by the rangers, that the rangers shot their dogs and that there was no communication between reserve staff and New Mandela Village residents. The New Mandela Village group also stated that they never see any wild animals so are puzzled about the purpose of the nature reserve; they see it as land that is not being used.

New Mandela Village residents had many suggestions about how the ABNR could help them meet their needs. These included suggestions that the reserve create a children's garden and find other ways to contribute to local children's education and aspirations. Also, New Mandela Village residents wanted to see reserve land be released for food cultivation. People in the area also wanted to use the ABNR for cattle grazing.

\section{Protected area management needs}

The GDACE officials from the Directorate of Nature Conservation hoped that the RRA consultation would enable them to do something 'good' for the community and also achieve a 'win-win' situation for the nature reserve. They hoped that residents of Khutsong would come to understand why the nature reserve land had been set aside for biodiversity conservation and that this understanding would reduce conflicts between the management of the protected area and the community.

Although not part of the RRA, it was recognised that a buffer zone was needed to mitigate the impact of the Khutsong settlement on the nature reserve. This need was articulated and negotiated over time by the first project manager, the late Mr Madire Malepe, with representatives of the Merofong Municipality and with affected residents of Khutsong, including those who participated in the original RRA. In creating the buffer zone, consideration was given to the fact that some of the shacks of Khutsong were already next to the boundary of the ABNR and because these shacks could not be moved back from the 'fence' to create the buffer, the buffer area was set inside the nature reserve, using nature reserve land.

\section{Lack of neighbour relations policy}

Before the interaction with Khutsong residents, the GDACE had a generic 'neighbour relations' policy, essentially about 'nurturing the community'. Once the Khutsong RRA was performed in 2000, a more realistic picture of community engagement emerged (although this did not constitute a replacement policy). Whilst post-RRA relations were very cordial, it was realised by the GDACE officials that a relationship with Khutsong residents would need to be 'toughed out' over time, whilst engaging in a spirit of openness, and that staff skilled in community liaison would need to be recruited and deployed. Over time, skilled staff were recruited to manage the two outreach projects and build the relationship with the community.

In response to the findings of the RRA in 2000, and in realising that the ABNR is very small, the management plan committee took the decision that no direct use of the nature reserve by the neighbouring Khutsong community would be considered, although there was no formal departmental policy on transferring benefits to communities. This stance was also informed by a medicinal plant study Dzerefos and Witkowski (2001), which recommended that no harvesting rights be bestowed on local traditional healers and medicinal plant traders.

Regular discussions about project challenges were held both at departmental level (in the form of GDACE quarterly review meetings) and at the level of the ABNR management plan committee.

\section{Final project selection}

The one-day RRA consultation with five Khutsong community groups in January 2000 enabled the GDACE's Directorate of Nature Conservation to plan a programme of two outreach projects linked to the nature reserve, whilst rejecting other suggestions from the community. Findings of the RRA indicated that most of the problems the residents of Khutsong and New Mandela Village faced were related to poverty and extreme deprivation, lack of work opportunities and poor municipal service delivery and had few links to the mandate of the ABNR or the core business of the GDACE (i.e. biodiversity conservation, food security and agriculture). This both limited and influenced the final project selection. In the final selection of projects for the outreach programme, some ideas and suggestions (both from the community and from conservation officials) had to be rejected as being outside the mandate of the GDACE, difficult to manage, or out of alignment with biodiversity conservation principles. For example, cattle grazing by the local community was considered initially as a potential 'benefit' but, in the end, was rejected by the province because of the difficulties in 
managing the equitable allocation of this benefit. Also, the community stated that they wanted to be allowed to hunt with dogs on the nature reserve, but this was deemed an unacceptable practice by the management plan committee. The community also wanted to receive meat from game culls on the reserve, as well animal parts to be used for 'muthi' [witchcraft purposes]. These latter requests were not practical, as most of the game surplus was sold live to game capture organisations. The request by the Bambanani Group for a medicinal tree plantation was also eventually refused by the GDACE ecologists on the grounds that these species were foreign to the typical grassland habitat of the ABNR and could become invasive over time.

During 2000 and 2001, a 50-metre wide strip along the western edges of the nature reserve was set aside to be developed as an agricultural project. The $50 \mathrm{~m}$ was easy to designate because of a gravel road which ran along the edge of the nature reserve, $50 \mathrm{~m}$ from where the fence line was originally located. This strip ran for approximately $6 \mathrm{~km}$ and provided 147 ha of land, or 3.5\% of the nature reserve land area, and was formalised in 2002. Officials also felt that the words 'buffer zone' were unpalatable in that it implied the intention to keep the community at bay; as such, the title 'Green Zone' was used for official communications.

The need for land for food gardens had been underestimated by the GDACE before the RRA consultation and it was agreed by provincial government that the Green Zone land could be released for food growing. A large portion of this was divided into 196 plots (indicating 196 lease holders) in the initial allocation. A plot size of $50 \mathrm{~m} \times 50 \mathrm{~m}$ (about $0.5 \mathrm{ha}$ ) was recommended by the GDACE Directorate of Agriculture as a viable plot size and this was also negotiated with the participants in various start-up meetings. Participants wanted small plots that were easy to manage. Allotment applicants were screened through an interview process according to their willingness to use the land according to the lease conditions, as well as whether they had prior experience in agriculture or vegetable growing.

A fenced plot (about $0.5 \mathrm{ha}$ ) of land within the nature reserve was also allocated to the Bambanani Group of traditional healers (14 recipients) in 2000 for medicinal plant cultivation. The group grew wild ginger (Siphonochilus aethiopicus) and African potato (Hypoxis hemerocallidea). A tap provided municipal water for the plants. The Bambanani Group also received training from the resident ABNR horticulturalist on cultivation methods.

A study was later commissioned by the GDACE to guide the development of an outreach medicinal plant nursery and overcome predicted failures (Botha 2003). The study showed how funding and support has to be provided for a considerable length of time before the projects are handed over to be run independently by the community (Botha 2003). Although the ABNR community projects were financed by provincial government, and an associated medicinal plant rescue scheme and infrastructure (greenhouses) was funded for three years (2006-2008) through the GTZ (Deutsche Gesellschaft für Technische Zusammenareit, now called GIZ or Deutsche Gesellschaft für Internationale Zusammenareit), the projects ultimately failed as a result of unexpected political reasons. Owing to the Khutsong border demarcation protests, the Gauteng provincial government adopted a holding position and only funded core salaries between 2003 and 2011. The GTZ funding ended in 2008 and was not renewed because of the border demarcation issue and, since then, the greenhouse has stood empty (GDARD staff, pers. comm., 25 March 2011). As a side note, the GDACE became the Gauteng Department of Agriculture and Rural Development (GDARD) in 2009. Vegetables continue to be cultivated on some of the 'Green Zone' plots (ABNR Officerin-Charge, pers. comm., 25 March 2011).

\section{Discussion}

\section{Protected area buffer zones in South Africa}

In South Africa, the National Environmental Management Act: Protected Areas Act 2003 (Republic of South Africa 2003) makes no provision for the declaration of buffer zones and thus any buffer zones have no legal status unless the land is purchased. SANParks (n.d.) have developed their own buffer zone policy to influence burgeoning development outside the national parks, particularly the Kruger National Park.

Gauteng Province, South Africa's most urbanised province, also has no over-arching buffer zone policy for its six protected areas, although urban development is encroaching rapidly on all these reserves. However, there are internal policies and 'guidelines' that deal with the types of development allowed around the protected areas. There is also no general neighbour relations policy to guide how benefits from protected areas are to be transferred (GDARD staff, pers. comm., 25 March 2011).

\section{What protected areas can mean in a 'township' context}

Since its proclamation as a nature reserve in 1977, the ABNR it has not been used by Black Khutsong and Carletonville residents as a recreational area, even in the post-1994 era and despite the very over-crowded conditions in Khutsong. Neither before nor after 1994 have the residents of Khutsong ever tried to claim the ABNR through land invasions. Whilst some living in New Mandela Village had erected their shacks inside the reserve, they had never gone further than a perimeter gravel road (50 $\mathrm{m}$ from the boundary fence). In fact, it would appear that most of the township seems indifferent to the nature reserve. Yet, the nature reserve has meaning for some groups.

The traditional healers (Bambanani Group) saw it as an area where the growing of medicinal plants could take place. The youth saw possibilities for hunting with dogs. Some people with an agricultural background (many of the eventual allotment holders) saw an opportunity to gain a small plot of land for cultivation. The home-based care group, the New Mandela Village Group and the Khutsong youth group, saw the potential educational value of the nature reserve. The value of the nature reserve to Khutsong residents is the sum of these perceptions and uses. 
Yet, the environmental education facility identified by Khutsong groups that were consulted has never materialised, despite the new facilities built on the ABNR (GDARD staff, pers. comm., 25 March 2011). This has been largely attributed to the impact of the border demarcation protests. The Abe Bailey outreach programme based on the RRA in 2000 also did not yield the large number of sustainable food gardens and medicinal plant gardens that were originally envisaged by both the Khutsong groups and the nature reserve management, and would have needed substantially more inputs from government, donors and the private sector to create sustainable benefits. Water and infrastructure for irrigation were the main constraints to the Green Zone agricultural activities, which could have been rectified with water storage tanks and pumping water from the nearby wetland to a high point and then using flood irrigation to water plots, but this would have required investment in a pump and cement ditch with sluice gates. At that stage, New Mandela residents used a 'pay-as-you-go' meter system to buy water for their households - a system that was regarded as 'very expensive' for householders. Yet, one lease holder produced 'enough spinach for sale' throughout the year by using household waste (grey) water, which he purchased from nearby shack owners.

Whilst SANParks has a detailed buffer zone policy, smaller protected areas such as the ABNR have to develop their own policy and, with minimal resources, implement this in an era with a strong development focus. Whilst there is still no formal buffer zone policy for the ABNR, or any overt patrolling of the border zone, it is apparent that the buffer zone land itself is somehow respected by the Khutsong residents (particularly the people of New Mandela Village) as a boundary, although trespass and arson continue. Since the GDACE-Khutsong engagement during 2000 and 2008, no new shacks have been erected in the buffer zone area, nor has there been encroachment of any kind beyond the buffer zone area into the nature reserve (Google Earth 2012). The only regulatory mechanism used to enforce the Green Zone was the one-year lease system and leases signed by allotment recipients in 2001. The lease arrangements have all now expired because of the border demarcation protests (ABNR Officer-in-Charge, pers. comm., 25 September 2010).

One of the important findings of this exercise was that the development of a community outreach programme does not depend solely on what either party (nature reserve management or community) needs, wants or demands, but depends, instead, on the sustained allocation of provincial resources (staff hours, capital expenditure, government budgets) or donor project funding to maintain relationships and a programme of work.

\section{The survival of small protected areas}

Maiorano et al. (2008) have warned that small protected areas in a human-dominated landscape will, in time, lose all the characteristics for which they have been established. To deal with this threat, conservation planners need to devote much more attention to the non-protected matrix in which their small protected areas exist and in which they must survive
(Maiorano et al. 2008). In the case of the ABNR, this would involve paying greater attention to changing land use within the wider area, as well as engaging with stakeholders other than Khutsong residents (i.e. municipal planners, farmers and agri-businesses). The Merafong IDP states that Merafong City is responsible for protecting environmentally sensitive areas within the municipal area from exploitation and damage resulting from direct or indirect urban development (Merafong Municipality 2011). The IDP also notes that the ABNR is one of several tourism areas and facilities located within the municipal area and acknowledges that important challenges facing the reserve are changes in land use causing a loss and fragmentation of natural habitat in surrounding areas, windborne and waterborne pollution, as well as socio-economic factors such as poverty that lead to the over-exploitation of natural resources (Merafong Municipality 2011).

The most surprising benefit of the Abe Bailey outreach programme was to the nature reserve staff, infrastructure and other assets. During the Khutsong provincial border demarcation riots of 2005-2007, the newly built nature reserve infrastructure valued at R7 million was spared vandalism and staff were not threatened. It is the view of the staff at the ABNR (ABNR Officer-in-Charge, pers. comm., 24 April 2011) and also the opinion of the late Mr Madire Malepe (2008) that this protection was largely the result of an improvement in relations between the ABNR and its neighbours since 2000 .

\section{Conclusion}

In South Africa, the National Environmental Management Act: Protected Areas Act 2003 (Republic of South Africa 2003) requires government-funded protected areas to provide 'benefits' to neighbouring communities and contribute to the development needs of poor communities on the outside of the reserve. In building relationships between small protected areas and neighbouring communities, there are many research and/or consultative approaches, such as the RRA method, which can help uncover issues and needs on both sides and identify relevant projects and interventions. Whether taking the form of outreach or community-based natural resource management, these programmes can take a long time to implement, mature and deliver benefits. Financial support, whether from government or donors, can falter along the way. Unexpected impacts, for example, from urban political unrest, can stall projects. Yet attending to (selected) development issues on the outside of protected areas through community liaison and joint projects may be a sound way to secure a protected area into a more violent and unstable urban future.

Surprisingly, just the act of engaging with the community in a fair and transparent way yielded positive results for the Abe Bailey programme, as the actual outreach projects were only marginally successful. Whilst incurring costs in terms of staff hours, building better relationships acted as a form of insurance against the threats that township protests can bring, as seen by the way that the ABNR did not suffer the kind of vandalism that other government properties suffered in Khutsong during 2003-2008. 


\section{Acknowledgements}

We wish to acknowledge the staff of the GDARD (formerly known as GDACE), including those in the Directorate of Conservation and the Directorate of Agriculture, who worked on both projects from 2000 to 2007. We also wish to acknowledge the contribution of the community groups within Khutsong.

\section{Competing interests}

The authors declare that they have no financial or personal relationship(s) which may have inappropriately influenced them in writing this article.

\section{Authors' contributions}

S.T. (University of the Free State) conducted the interviews with GDARD officials, reviewed the written material and records from the original project and wrote the manuscript. D.A. (University of the Free State) as the second author was responsible for conceptual contributions and suggestions.

\section{References}

Adams, W.M., Aveling, R., Brockington, D., Dickson, B., Elliott, J., Hutton J. et al., 2004 'Biodiversity conservation and the eradication of poverty', Science 306(5699), 1146-1149. http://dx.doi.org/10.1126/science.1097920, PMid:15539593

Baker, J., Milner-Gulland, E. \& Leader-Williams, N., 2011, 'Park gazettement and integrated conservation and development as factors in community conflict at Bwindi Impenetrable Forest, Uganda', Conservation Biology 26(1), 160-170. http://dx.doi.org/10.1111/j.1523-1739.2011.01777.x, PMid:22044616

Bajimaya, S., 2006, 'Nepal's Buffer Zone programme: A showcase of a participatory approach to protected area management', in P. Gyamtsho, B.K. Singh \& G. Rasul (eds.), Capitalisation and sharing of experiences on the interaction between forest policies and land use patterns in Asia: Linking people with resources, vol. 2, Technical papers, p. 125-141, International Centre for Integrated Mountain Development, Kathmandu.

Botes, L., Lenka, M., Marais, L., Matebesi, Z. \& Sigenu, K., 2007, The cauldron of local protests: Reasons, impacts and lessons learned, Centre for Development Support, University of the Free State, Bloemfontein.

Botha, J., 2003, 'A preliminary study towards the setting up on an operational medicinal plant nursery at Abe Bailey Nature reserve', Draft report to the Gauteng Department of Agriculture, Conservation and Environment, Johannesburg.

Botha, J., Witkowski, E.T.F. \& Cock, J., 2006, 'The South African experience of conservation and social forestry outreach nurseries', Journal of Environmental Management 38, 733-749. http://dx.doi.org/10.1007/s00267-005-0184-4 PMid:16508799

Botha, J., Witkowski, E.T.F. \& Cock, J., 2007, 'Is something better than nothing'? The impacts of ten outreach nurseries on South African community stakeholders', Forests, Trees and Livelihoods 17, 199-221.

Browder, J.O., 2002, 'Conservation and development projects in the Brazilian Amazon: Lessons from the Community Initiative Program in Rondônia', Journal of Environmental Management 29(6), 750-762. http://dx.doi.org/10.1007/s00267Environmental Management

Chambers, R., 1994, 'The origins and practice of participatory rural appraisal', World Development 22(7), 953-969. http://dx.doi.org/10.1016/0305-750X(94)90141-4

Defries, R., Hansen, A., Turner, B.L., Reid, R. \& Liu, J., 2007, 'Land use change around protected areas: management to balance human needs and ecological function' Ecological Applications 17, 1031-1038. http://dx.doi.org/10.1890/05-1111, PMid:17555216

Department of Environmental Affairs and Tourism, 1997, 'White paper on the conservation and sustainable use of South Africa's biological diversity', General Notice 1095 of 1997, DEAT, Pretoria, viewed 28 March 2012, from http://www. environment.gov.za/PolLeg/WhitePapers/Biodiversity/Contents.htm

Dzerefos, C.M. \& Witkowski, E.T.F., 2001, 'Density and potential utilization of medicinal grassland plants from Abe Bailey Nature Reserve, South Africa', Biodiversity and Conservation 10, 1-22.

Eber, S., 1998, 'Establishment of task team for approval by the Head of Department', Internal departmental memo within the Department of Agriculture, Conservation and Environment, Johannesburg.

Gimmi, U., Schmidt, S.L., Hawbaker, T.J., Alcántara C., Gafvert U. \& Radeloff V.C., 2011 'Increasing development in the surroundings of US National Park Service holdings jeopardizes park effectiveness', Journal of Environmental Management 92(2011), 229-239.
Gjertsen, H., 2005, 'Can habitat protection lead to improvements in human wellbeing? Evidence from marine protected areas in the Philippines', World Deing? Evidence from marine
Development 33(2), 199-217.

Google Earth, computer software, viewed 28 March 2012, from http://www. maplandia.com/south-africa/guateng/oberholzer/khutsong/

Guo Z., Zhang L. \& Li Y., 2010, 'Increased dependence of humans on ecosystem services and biodiversity', PLOS ONE 5(10), e13113, viewed 10 November 2011 from http://dx.doi.org/10.1371/journal.pone.0013113

Iwamura, T., Wilson, K.A., Venter, O. \& Possingham, H.P., 2010, 'A climatic stability approach to prioritizing global conservation investments', PLOS ONE 5(11) e15103, viewed 10 November 2011, from http://dx.doi.org/10.1371/journal. pone.0015103

Joppa, L.N., Loarie, S.R. \& Pimm, S.L., 2009, 'On population growth near protected areas', PLoS ONE 4(1), e4279, viewed 10 November 2011, from http://dx.doi. org/10.1371/journal.pone.0004279, PMid:19169358

Kintz, D.B., Young, K.R. \& Crews-Meyer, K.A., 2002, 'Implications of land use/land cover change in the buffer zone of a national park in the tropical Andes', Journal of Environmental Management 28(2), 238-252.

Lynagh, F.M. \& Urich, P.B., 2002, 'A critical review of buffer zone theory and practice: A Philippine Case Study', Society and Natural Resources 25, 129-145. http://dx.doi. org/10.1080/089419202753403319

Ma, Z., Li, B., Lil, W., Han, N., Chen, J. \& Watkinson, A., 2009, 'Conflicts between biodiversity conservation and development in a biosphere reserve', Journal of Applied Ecology 46, 527-535. http://dx.doi.org/10.1111/j.1365-2664.2008.01528.x

Maiorano, L., Falcucci, A. \& Boitani, L., 2008, 'Size-dependent resistance of protected areas to land-use change', Proceedings of the Royal Society B: Biological Sciences 275(1640), 1297-305. http://dx.doi.org/10.1098/rspb.2007.1756, PMid:18319213

Malepe, M., 2008, e-mail, 18 July, email address unknown.

Mascarenhas, J., 1991, 'Participatory rural appraisal and participatory learning methods: Recent experiences from Myrada and South India', RRA Notes 1991 13, 26-32, viewed 28 March 2012, from http://pubs.iied.org/pdfs/G01399.pdf

Mavungu, E.M., 2011, 'Explaining boundary disputes in post-Apartheid South Africa: Bushbuckridge, Matatiele and Khutsong', PhD thesis, Department of Political Studies, University of the Witwatersrand, viewed 28 March 2012, from http:// wiredspace.wits.ac.za/bitstream/handle/10539/10945/Phd\%20thesis\%20 mazembo_final\%20version.pdf?sequence $=2$

Mbile, P., Vabi, M., Meboka, M., Okon, D., Arrey-Mbo, J., Nkongho, F. et al., 2006, 'Linking management and livelihood in environmental conservation: Case of the Korup National Park, Cameroon', Journal of Environmental Management 76(1) 1-13. http://dx.doi.org/10.1016/j.jenvman.2005.01.009, PMid:15854732

Merafong Municipality, 2011, The Merafong City integrated development plan 2011/2012. Annexure J8: Growth and development strategy - Section 4, viewed 28 March 2012, from http://www.merafong.gov.za/DataFiles/file/IDP\%202011\%20 12/Annexure\%20J\%208\%20-Growth\%20\&\%20Development\%20Strategy.pdf

Mulder, M.B., Caro, T. \& Msago, O.A., 2007, 'The role of research in evaluating conservation strategies in Tanzania: The case of the Katavi-Rukwa ecosystem' Conservation Biology 21(3), 647-658. http://dx.doi.org/10.1111/j.15231739.2007.00703.x, PMid:17531043

Reid, H., Fig, D., Magome, H. \& Leader-Williams, H., 2004, 'Co-management of contractual national parks in South Africa: Lessons from Australia', Conservation and Society 2(2), 377-409.

Republic of South Africa, 2003, National Environmental Management: Protected Areas Act 2003 (Act No. 57 of 2003), Government Gazette 464(26025), 1-26.

Secretariat of the Convention on Biological Diversity, 2008, 'Protected areas in today's world: Their values and benefits for the welfare of the planet', CBD Technical Series 36, i-vii, 1-96.

Seiferling, I.S., Proulx, R., Peres-Neto, P.R., Fahrig, L. \& Messier, C., 2011, 'Measuring protected-area isolation and correlations with land-use intensity and protection status', Conservation Biology. http://dx.doi.org/10.1111/j.15231739.2011.01674.x

Sodhi, N.S., Lee, T.M., Sekercioglu, C.H., Webb, E.L., Prawiradilaga, D.M., Lohman, D.J. et al., 2010, 'Local people value environmental services provided by forested parks', Biodiversity Conservation 19, 1175-1188. http://dx.doi.org/10.1007/ s10531-009-9745-9

South African National Parks, n.d., 'Draft policy on buffer zones for national parks', SANParks, Pretoria.

Spiteri, A. \& Nepal, S.K., 2008, 'Evaluating local benefits from conservation in Nepal's Annapurna Conservation Area', Journal of Environmental Management 42(3), 391-401. http://dx.doi.org/10.1007/s00267-008-9130-6, PMid:18458999

Straede, S. \& Treue, T., 2006, 'Beyond buffer zone protection: A comparative study of park and buffer zone products' importance to villagers living inside Royal Chitwan National Park and to villagers living in its buffer zone', Journal of Environmental Management 8(3), 251-267.

Wells, M.P. \& McShane, T.O., 2004, 'Integrating protected area management with local needs and aspirations', AMBIO: A Journal of the Human Environment 33(8), 513-519. http://dx.doi.org/10.1579/0044-7447-33.8.513

Wittemyer, G., Elsen, P., Bean, W., Burton, A.C. \& Brashares, J., 2008, 'Accelerated human population growth at protected area edges', Science 321, 123-126. http:// human population growth at protected area edges', Scienc
dx.doi.org/10.1126/science.1158900, PMid:18599788

Wittmayer, J. \& Büscher, B., 2010, 'Conserving conflict? Transfrontier conservation, development discourses and conflict between South Africa and Lesotho', Human Ecology 38(6), 763-773.

Wynberg, R., 2002, 'A decade of biodiversity conservation and use in South Africa: Tracking progress from the Rio Earth Summit to the Johannesburg Wold Summit on sustainable development', South African Journal of Science 98, 233-243. 